\title{
Migrant and refugee populations: a public health and policy perspective on a continuing global crisis
}

\author{
Mohamed Abbas $^{1 *}$ (D), Tammam Aloudat ${ }^{2}$, Javier Bartolomei ${ }^{3}$, Manuel Carballo ${ }^{4}$, Sophie Durieux-Paillard ${ }^{5}$, \\ Laure Gabus ${ }^{6}$, Alexandra Jablonka ${ }^{7,8}$, Yves Jackson ${ }^{9,10}$, Kanokporn Kaojaroen ${ }^{11}$, Daniel Koch ${ }^{12}$, Esperanza Martinez ${ }^{13}$, \\ Marc Mendelson ${ }^{14}$, Roumyana Petrova-Benedict ${ }^{15}$, Sotirios Tsiodras ${ }^{16,17}$, Derek Christie ${ }^{18}$, Mirko Saam ${ }^{19}$, \\ Sally Hargreaves ${ }^{20,21}$ and Didier Pittet $^{1}$
}

\begin{abstract}
The 2015-2017 global migratory crisis saw unprecedented numbers of people on the move and tremendous diversity in terms of age, gender and medical requirements. This article focuses on key emerging public health issues around migrant populations and their interactions with host populations. Basic needs and rights of migrants and refugees are not always respected in regard to article 25 of the Universal Declaration of Human Rights and article 23 of the Refugee Convention. These are populations with varying degrees of vulnerability and needs in terms of protection, security, rights, and access to healthcare. Their health status, initially conditioned by the situation at the point of origin, is often jeopardised by adverse conditions along migratory paths and in intermediate and final destination countries. Due to their condition, forcibly displaced migrants and refugees face a triple burden of non-communicable diseases, infectious diseases, and mental health issues. There are specific challenges regarding chronic infectious and neglected tropical diseases, for which awareness in host countries is imperative. Health risks in terms of susceptibility to, and dissemination of, infectious diseases are not unidirectional. The response, including the humanitarian effort, whose aim is to guarantee access to basic needs (food, water and sanitation, healthcare), is gripped with numerous challenges. Evaluation of current policy shows insufficiency regarding the provision of basic needs to migrant populations, even in the countries that do the most. Governments around the world need to rise to the occasion and adopt policies that guarantee universal health coverage, for migrants and refugees, as well as host populations, in accordance with the UN Sustainable Development Goals. An expert consultation was carried out in the form of a pre-conference workshop during the 4th International Conference on Prevention and Infection Control (ICPIC) in Geneva, Switzerland, on 20 June 2017, the United Nations World Refugee Day.
\end{abstract}

Keywords: Migrant populations, Refugees, Crisis, Global health, Public health policy, Infectious diseases

\section{Background}

The current global refugee crisis peaked in 2015-2016, and by late 2017 the number of people attempting to cross borders globally - although still high - was receding. The highest levels of forced displacement since World War II were observed in 2015, with a dramatic increase in the numbers of refugees, asylum-seekers and

\footnotetext{
* Correspondence: mohamed.abbas@hcuge.ch

${ }^{1}$ Infection Control Programme and WHO Collaborating Centre on Patient

Safety, Faculty of Medicine, University of Geneva Hospitals, Geneva,

Switzerland

Full list of author information is available at the end of the article
}

internally displaced people (IDPs) across the world - from Africa to the Middle East and South Asia. "Desperate" migration towards Europe became increasingly seaborne with over one million migrants arriving by boat in Greece and Italy in 2015. Such operations are highly risky; in the Mediterranean, several thousand migrants have drowned every year since 2014 . At the global level, at least $60^{\prime} 000$ migrants have died or gone missing over the past 20 years [1]. Although statistics on migration are difficult to collect, it is necessary to avail oneself of the available data which should be viewed as estimates (Fig. 1) [2].

(c) The Author(s). 2018 Open Access This article is distributed under the terms of the Creative Commons Attribution 4.0 International License (http://creativecommons.org/licenses/by/4.0/), which permits unrestricted use, distribution, and 


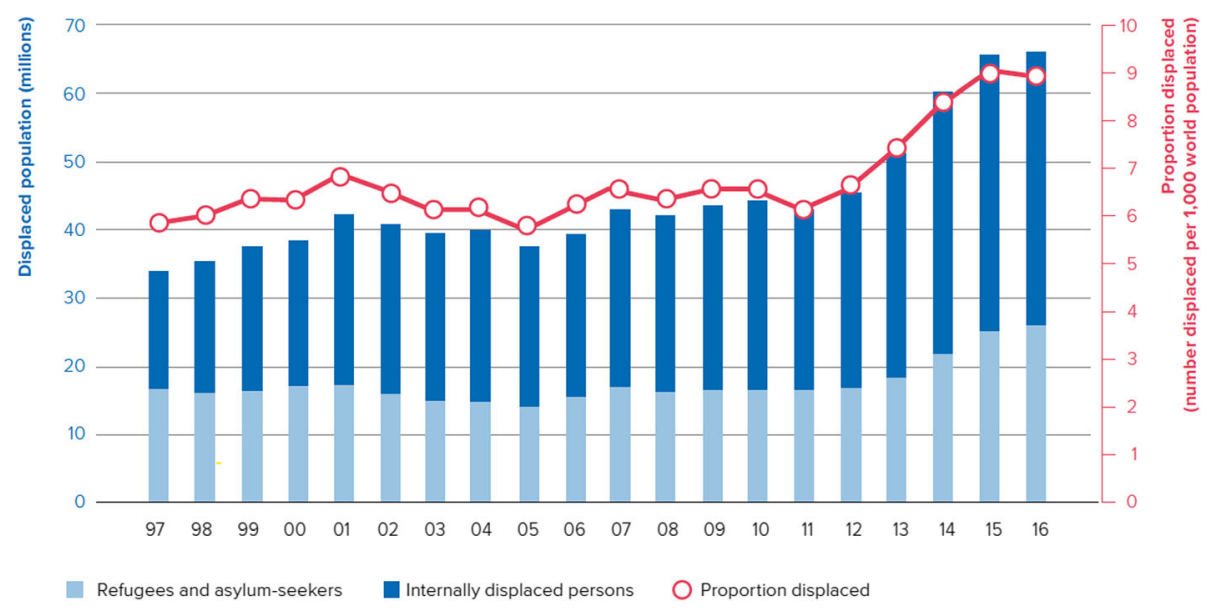

Fig. 1 Estimates (in millions) of the global numbers of migrants 1990-2016. ๑ UNHCR, reproduced with permission

For purposes of ease of reading, and because we believe that the current nomenclature is arbitrary, in this paper we will use the International Organization for Migration's (IOM) definition, and refer to a migrant as "any person who is moving or has moved across an international border or within a State away from his/her habitual place of residence, regardless of (1) the person's legal status; (2) whether the movement is voluntary or involuntary; (3) what the causes for the movement are; or (4) what the length of the stay is." [3] We will use the term interchangeably with the words refugees and asylum-seekers, whether documented or not.

A hallmark of global migration patterns is that IDPs are the highest in number, and low and middle-income countries host most of the world's refugees. In 2016, Turkey had more than 3 million refugees and asylumseekers on its soil, including 2.7 million Syrians; Lebanon had the highest number relative to its population, nearly one in five inhabitants is a refugee. Of this, the United Nations (UN) Secretary General, António Guterres, said "It is so inspiring to see countries with the least often doing the most for refugees" [4]. In this context, the so-called European "migrant crisis" pales in comparison, and perhaps a change in perspective is required, as in Natalie Nougayrède's words:

"If there was a crisis in 2015, it had less to do with the refugees - who knew what they were fleeing and where they wanted to go - and much more to do [sic] with European governments and societies who did not all step up to the plate. In fact, Europe isn't confronted with a refugee and migrant crisis. It's the refugees and migrants who are confronted with a crisis of Europe. The scandal is that, in the Mediterranean, they have been paying with their lives." [5]
The reasons for forced migration and displacement are increasingly varied, but stem from fragility of states, due to armed conflict and civil unrest, extreme poverty, crime, persecution (including political discrimination), failure of governance, or climate change [6-8]. Over half of the refugees globally come from three countries: Syria, Afghanistan and Somalia; yet refugees are the tip of the iceberg, when one considers the number of IDPs. Altogether, more than 1.5 billion people live in the 56 fragile states that engender refugees [9].

On the occasion of the UN World Refugee Day, 20 June 2017, we conducted an expert consultation in the form of a pre-conference workshop during the 4th International Conference on Prevention and Infection Control (ICPIC) in Geneva.

\section{Basic needs and rights}

The 1951 Refugee Convention guarantees basic rights such as liberty, security, right to family life, protection, and freedom of movement [10]. Refugees are therefore not to be returned to their home country against their will. Other basic needs include the right to education and justice. Also, article 23 of the Refugee Convention guarantees the right of refugees to public relief, that is, to access physical and mental health services at the same level as other residents. This fundamental right is also guaranteed by article 25 of the Universal Declaration of Human Rights [11].

In the present crisis, these basic rights have not always been met. While there have been some advances in the form of migrant-friendly hospitals, health systems overall are not sufficiently responsive to migrants, to diversity, or to specific medical and psychosocial care. A needs-based approach is required to address these issues. 
Beyond basic needs, migrants, like all humans, aspire to self-actualisation, have hopes and dreams, and demand dignity (Figs. 2 and 3). They need to be considered as human beings, beyond the stereotypes entertained by certain host populations, and to be freed from any form of discrimination, as indeed assumptions and prejudice inform many political decisions. The humanitarian response in the field also needs to take into account the importance of maintaining communication with those left behind, because of its strong links to psychosocial health and well-being. The first thing that many look for when they have survived a sea-crossing is wireless local area networking ("WiFi") - to inform and obtain news from loved ones [12]. Social isolation is also a reality, with over two-thirds of migrants stating that needs for social contact were unmet, and this has direct mental health consequences $[13,14]$.

\section{Universal health coverage}

First recognised by the UN in 2010 [15], the commitment to universal health coverage was subsequently reinforced [16] and is a core component of sustainable development at the global level [17-19]. It requires that all people have access to health services - including prevention, treatment, rehabilitation and palliative care - without risk of financial hardship [20]. Its impact on migrants' health would be even more positive if this policy were embedded into a broader perspective of universal social rights coverage as put forward by the International Convention on the Protection of the Rights of All Migrant

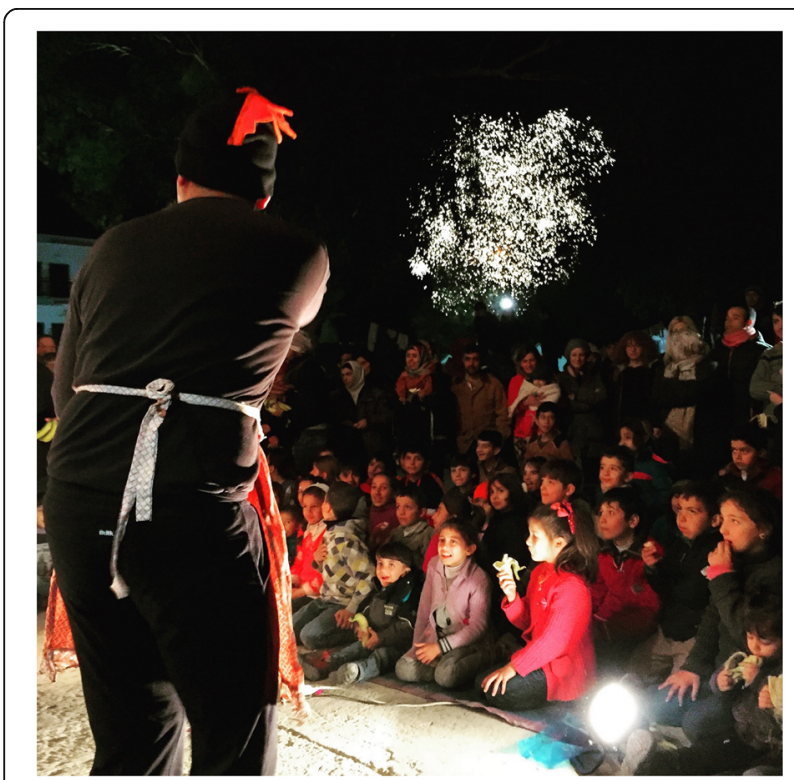

Fig. 2 A Greek theatre company gives a show in a refugee camp in Leros. The play, in Greek, is about a little black fish lost in the ocean. None of the spectators understand, but everyone is laughing. (C) Laure Gabus

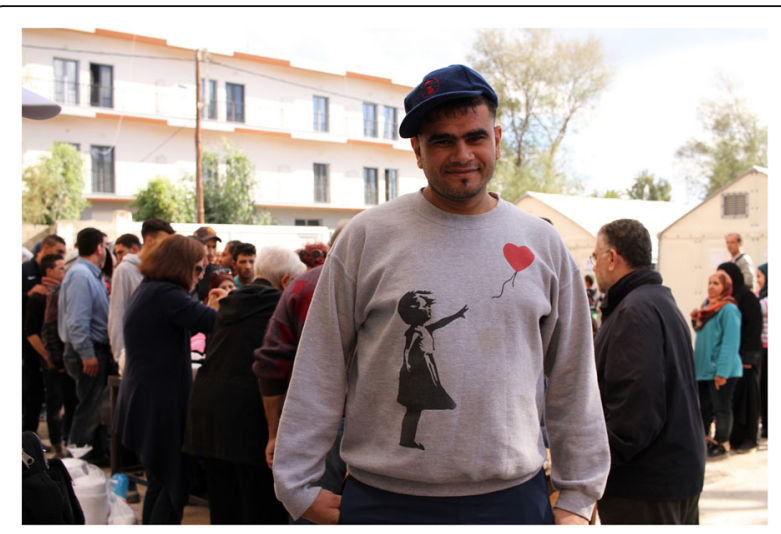

Fig. 3 Man posing in the refugee camp during the Sunday meal distribution organized by Leros' residents. He has just received new clothes, distributed by mutual aid associations. On his jumper, a Bansky drawing. Most smugglers ask migrants to get rid of their luggage before crossing the Aegean Sea so as not to weigh down the inflatable boat. (c) Laure Gabus

Workers and Members of Their Families adopted by United Nations General Assembly resolution 45/158 of 18 December 1990.

For universal health coverage to occur, research and public health action must take place all along the migratory route, not just upon arrival in a host country. The health status and challenges of many migrating populations are insufficiently addressed until they arrive in a high-profile country. There is, therefore, a clear need to provide and improve healthcare along migration routes. This requires the alignment of the public health and humanitarian agendas, all the more so because health and social systems along the way are often weak.

\section{Vulnerability}

The unprecedented number of forcibly displaced migrants is compounded by increasing demographic, socio-economic, and medical complexity. For example, the global number of child refugees has reached alarming levels: at least 300,000 unaccompanied children moving across borders were registered over two years in 2015-2016, representing a nearly five-fold increase from 2010 to 2011 [21]. Proportions of pregnant women, the elderly and people with disabilities halve also increased in the past years. Migrants are more than ever a heterogeneous group, migrants in irregular status can often be averse to sharing personal details with any administration - including hospitals or medical services out of fear and/or distrust. Their motivations or even their desired destination may change during the journey. This unprecedented diversity leads to an extended range of medical requirements $[22,23]$ as well as complex gender and social issues [24-26].

The "healthy migrant" hypothesis suggests that self-selection prior to migration leads to the observation that 
upon arrival, migrants tend to be younger and fitter than host (or origin) populations [27]. Emerging knowledge on the evolution of newcomers' health shows that this effect subsides over time, and that migrant health deteriorates after several years due to poverty, poor living conditions, and restricted access to healthcare [27, 28]. The healthy migrant effect may therefore be called into question, as has been suggested by several authors [27, 29, 30].

Violence is a key risk factor for forcibly displaced migrants. In studies in Médecins Sans Frontières (MSF) mental health clinics in Serbia, up to a third of migrants were found to have been victims of violent events [31]. Potentially traumatic events were experienced by $60 \%$ and $90 \%$ of migrants in their home country and during migration, respectively [32]. In Morocco, among 154 sub-Saharan migrants, $90 \%$ reported cases of multiple victimizations, $45 \%$ of which were sexual, predominantly gang rape; 79 respondents (51\%) were personally victimized, and $27 \%$ were forced to witness relatives or co-migrants being victimized [33]. Prisons in all countries are prone to violence, and some administrative detention centres can be even more violent than civilian prisons, due to the absence of rights traditionally granted to prisoners [34], and failiure to follow the UN Standard Minimum Rules for the Treatment of Prisoners ("the Nelson Mandela" rules) [35]. The proportions of foreign inmates in prisons can be very high (e.g. $72 \%$ in Switzerland); some are undocumented migrants in administrative detention [36, 37]. Also, due to overcrowding, these are settings where the transmission of infectious diseases of public health interest can occur, especially tuberculosis and sexually transmitted diseases such as syphilis, HIV and hepatitis [38, 39].

In practice, clustering often occurs in migrant populations, with several diseases or conditions affecting the same individuals or groups. This is due to shared vulnerabilities, lack of financial resources, length and duration of the journey and many intermediate destinations, in addition to the epidemiological burden in the country of origin. There are specific risks for women, children (especially unaccompanied minors) and the elderly. Overcrowding and deficient water and sanitation in camps and reception facilities increase risks related to infectious diseases, e.g. vaccine-preventable diseases. Thereafter, restrictive policies in the destination country affect living conditions by limiting access and accessibility to healthcare, education, labour market as well as increasing language and other communication barriers [40].

The concept of syndemics (synergistic epidemics) can be useful to approach the clustering of certain risk factors or diseases, in certain populations and settings [41]. For example, in a context of migratory stress, synergy between infectious diseases, metabolic diseases and mental health would yield a worse outcome (Fig. 4). Syndemics such as SAVA (substance abuse, violence and AIDS) or VIDDA (violence, immigration, diabetes, depression and abuse) serve as pertinent examples [41].

\section{Medical footprint and burden of disease}

The medical footprint is a useful framework to understand each migrant's personal health capital and its evolution. Whenever a person decides to move, they bring with them a social, cultural and economic capital, which is liable to change during the trajectory of the individual through time and space. Each migrant also has a personal health capital, which will also evolve during their journey from their home country to an eventual destination. It is important to take into account migrants' health capital, and its evolution, the latter being impacted by social determinants of health, and advocate for enabling polices to maintain and develop it. This is important for health equity - universal coverage cannot be realised if certain populations are left aside - but also because there are interactions between migrant and host populations. This dynamic sequence of events can be divided into six stages, each characterised by shortages and medical implications (Table 1).

Even if, and it is hardly ever the case, healthcare may be available and relatively accessible when migrants arrive in a host country, this rarely compensates the months and years spent in either a risk-ridden and often prolonged transit phase, or at the point of origin [42]. For migrants, there usually is a succession of stressful incidents or phases: the experience of exile itself, followed by fear linked to life-threatening situations such as crossing the Mediterranean on an overcharged boat, and then administrative anguish as they wait for applications to be processed in a camp or underground shelter. A further stressor might be the uncertainty of their future in a potential host country. Moreover, exposure to conflict and war has a lasting impact on mental health. Due to these life events, the prevalence of psychiatric disorders in refugee populations is much higher than in those not forcibly displaced [14, 43-45]. The link between environmental and psychological stress and adverse health outcomes is well documented. Mental health conditions including anxiety and depression are associated with certain infectious diseases, as has been suggested in a recent review [46].

Forcibly displaced populations are increasingly facing the triple burden of chronic non-communicable diseases (e.g. diabetes, cardiovascular diseases, respiratory conditions and cancer), infectious diseases (e.g. tuberculosis, HIV, hepatitis), and psychiatric illnesses (e.g. post-traumatic stress disorder, depression). A recent survey of a Jordanian camp mainly populated by Syrian refugees indicated prevalence rates for hypertension of $21 \%$ and $52 \%$, cardiovascular disease of $7.5 \%$ and $21 \%$, diabetes of $12 \%$ and $32 \%$, in the $40-59$ and $60+$ age groups, respectively [47]. Due to the increasing complexity and 


\section{Syndemic model}

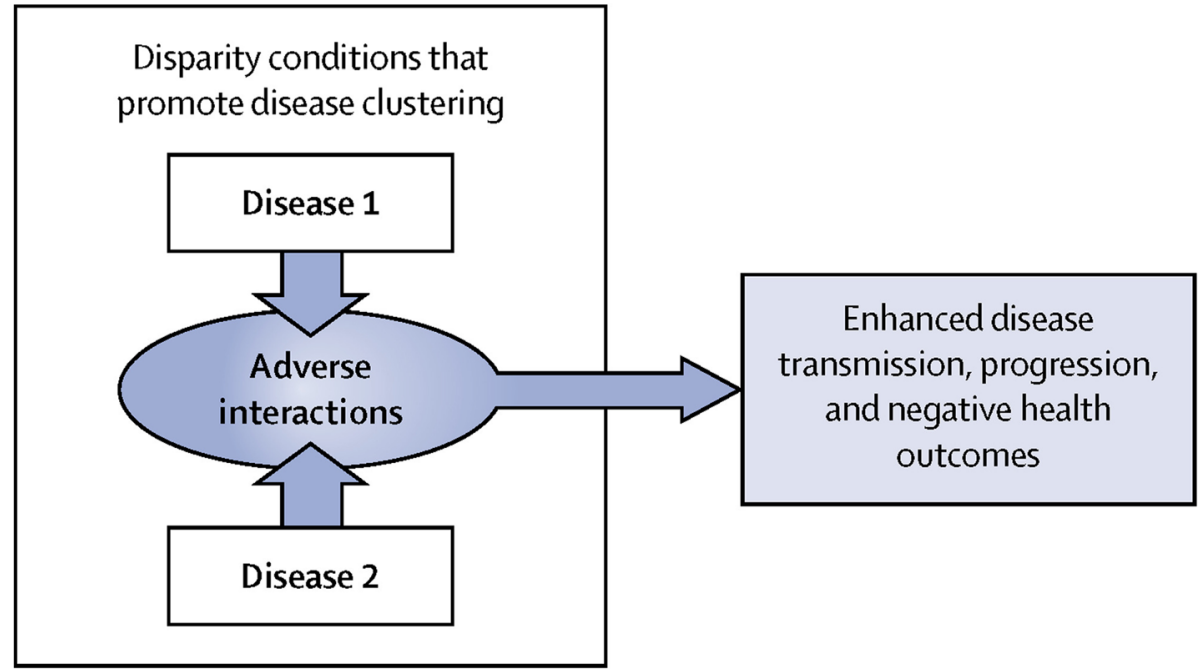

Fig. 4 The syndemic model. Reproduced with permission from [41]

diversity of migrant populations, there is also the problem of overlapping medical conditions further perplexing appropriate interventions. Increasingly, polymorbidity, often arising at a premature life stage, becomes a challenge among forced migrants in Europe [48]. The impact of community-acquired infections leading to admission to intensive care units seems much higher in refugees in host countries than in the autochthonous population $[49,50]$.

\section{Infectious diseases}

The prevalence of certain chronic parasitic diseases in asymptomatic migrants reflects, in general, the

Table 1 Key steps and health determinants of migrants' health - medical footprint

\begin{tabular}{lll}
\hline Step & Main problems/issues & Shortages \\
\hline 1. Pre-migration health experience & $\begin{array}{l}\text { Local epidemiological situation and poverty, } \\
\text { conflict and war }\end{array}$ & $\begin{array}{l}\text { Diagnosis, vaccination, healthcare, clean water, } \\
\text { adequate housing, personal safety }\end{array}$
\end{tabular}

2. Transit health experience

Long in time and space, often worse than in country of origin

\section{Destination experience}

4, Healthcare access/use experience

5. New transit experience

6. Final destination experience
Unfavourable and unhealthy. Lasting situations governed by the will to survive. Adverse weather conditions outdoors, or if indoors overcrowded conditions and risk of transmission of infectious diseases among migrants

Fear of the law, suspicion of giving out personal data and the general feeling of not being appreciated may affect the evaluation by migrants of their right to access healthcare and other services

There are often several transit experiences, for instance through North Africa and Southern Europe; through Turkey and the Balkans; or through Central America and Mexico

If and when a migrant finds a job, it is often dirty, dangerous and degrading ("3 Ds"). It may also be illegal, with no insurance coverage and limited access to healthcare. These informal jobs are vitally important for the economies of high-income countries
Water, nutrition, hygiene, sanitation, housing (overcrowding), social and sexual protection (hostility of resident populations, exploitation by criminal gangs). Exposure to new pathogens for which they have no immunity

Lack of appropriate clothes, shoes and personal belongings (often abandoned, lost or stolen before or during sea crossings), lack of psychosocial support

Trained healthcare personnel

Water, nutrition, hygiene, sanitation, housing (overcrowding), social and sexual protection (hostility of resident populations, exploitation by criminal gangs). Exposure to new pathogens for which they have no immunity

Lack of appropriate clothes, shoes and personal belongings (often abandoned, lost or stolen before or during sea crossings), lack of psychosocial support 
epidemiologic burden at the country of origin and may be high, up to $5.8 \%, 48.5 \%$, and $56.1 \%$, for schistosomiasis, Chagas disease, and strongyloidiasis respectively, according to one report [51]. Knowledge of such "tropical diseases", which may be a misnomer as they have become global, is imperative for proper patient management. Furthermore, more efforts should be undertaken to include migrants in programmes aiming to eradicate neglected tropical diseases [52]. The prevalence of chronic viral diseases, such as HIV, hepatitis C (HCV), and hepatitis B is also higher than in host populations and can be as high as $2.3 \%, 1.3 \%$, and $14 \%$, respectively, depending on country of origin [51]. Co-infections, e.g. between viral and parasitic infections increase susceptibility to infection, risk of transmission, as well as severity and progression of the disease [53-56]. This may be particularly concerning for chronic viral infections that lead to cancer, such as chronic hepatitis associated hepatocellular carcinoma, or human papillomavirus associated cervical precancerous and cancerous lesions [57]. Migration into Europe is changing the epidemiology of many diseases, including HCV. If the goal of $\mathrm{HCV}$ eradication is to be achieved, more inclusive policies and practices will be required [58].

Epidemiological screening is a legitimate tool to better study the profile of migrant populations and to understand their needs [59, 60]. In developing countries facing high rates of internal displacements, there is an urgent need to unify screenings and treatments, and to fight the as yet largely unaddressed problem of counterfeit medicines. In the more developed destination countries, screening of migrant populations seeking healthcare may also help to understand and control the inter-country spread of antibiotic resistance [61]. Health assessment on arrival is a useful way of gaining an initial understanding of the health of incident migrant populations. Screening can be systematic or performed on a case-to-case basis, whereupon arrival, each migrant obtains a personal consultation to describe their medical and transit history $[59,60]$. Based on this information, the physician can decide whether to test the person for an array of medical conditions. One such EU-level initiative is the development of the electronic personal and health record, Re-Health (http://re-health.eea.iom.int/). A recent systematic review has estimated that approximately $3 \%$ of screened individuals have an infectious disease, but $15 \%$ have latent tuberculosis [62]. Furthermore, it was shown that not only is uptake of screening high by migrant populations, but that screening is an effective strategy with moderate/high cost-effectiveness [62]. Evidence also shows positive cost-effectiveness and public health effects of screening and providing early treatment to Latin American women of child-bearing age at risk of suffering and transmitting Chagas disease outside endemic countries [63, 64].

\section{Vaccine-preventable diseases and vaccination}

Screening can also include assessment of immunity to vaccine-preventable diseases. Several studies have shown that vaccination coverage of migrants on arrival is insufficient, although heterogeneity exists between different countries of origin [65-69]. A recent study in Denmark has shown that one third of asylum-seeking children were not immunised in accordance with the national guidelines [65]. This incomplete immunisation may have consequences in terms of outbreaks in refugee camps [70-72].

The WHO-UNHCR-UNICEF Joint Technical Guidance recommends that migrants should be immunized according to the immunisation schedule of the country in which they intend to stay for more than 1 week [73]. It also states that access should be "non-discriminatory and equitable", and that measles-mumps-rubella (MMR) and polio vaccines should be a priority [73]. A similar strategy is also endorsed by the ECDC [74]. Unfortunately, many countries in Europe have yet to put in place directives on immunisation of migrants [75]. Implementing this strategy, however, is not without challenges related to the migrant condition (lack of information on immunization status, high mobility of migrants, economic difficulties), and further efforts are required in order to harmonise practices and improve communication between host countries and/or agencies [69, 76].

Benefits of achieving adequate vaccine coverage include a decrease in the burden of infectious diseases, and prevention and/or termination of outbreaks; as such, there has recently been interest in the effects of vaccination in reducing AMR [77-80]. It has been previously shown that vaccination strategies against Haemophilus influenzae and Streptococcus pneumoniae have been associated with decreases in the incidence of infections with resistant pathogens [77-80]. Presumably, one of the several proposed mechanisms would be mediated by decreases in the overall incidence of disease, including that of resistant strains as well as decreases in transmission of antibiotic resistant strains, although further research is required in order to fully understand and develop models $[80,81]$.

\section{Health risks: For us or for them?}

It has been known for many years that human mobility is linked to transmission, but also susceptibility, to infectious diseases. Movement of people, animals and goods has allowed dissemination of infectious diseases at least since 1000 B.C. [82]. Often, the health risk for the host populations has been politicised by various political groups with an anti-immigration agenda (e.g. Front National in France, Alternative für Deutschland in Germany, Schweizerische Volkspartei in Switzerland) to create a climate of fear surrounding migration. To counter this, the European Centre for Disease Control and Prevention (ECDC) produced a 
technical document which states that newly-arrived migrants and refugees "do not represent a significant risk for EU/EEA populations" with regards to communicable diseases [83]. This document also states that the risk to refugees has increased due to overcrowding at reception facilities, with the potential for increased transmission of entities like meningococcal disease, measles, varicella and influenza.

Antimicrobial resistance may be considered an emerging infectious disease, and is clearly linked to human mobility [84, 85]. Prevalence of carriage of methicillin-resistant Staphylococcus aureus and multi-drug resistant Enterobacteriaceae in migrant populations may be as high as 27\% [61, 85-87]. Migrants are also overrepresented in terms of multi-drug resistant tuberculosis compared to host populations [88]. A recent systematic review suggests that migrants might acquire antimicrobial-resistant pathogens during the migration process or once they have arrived in the host country; indeed, the prevalence of AMR in the latter would be a major determining factor in transmission to migrants [87]. This may have implications for infection control policies if migrants are hospitalised in low-endemicity settings, as is the case for returned travellers and repatriated patients. Epidemiological screening may be a legitimate tool to better study the profile of migrant populations and understand their needs, and may also help understand and control the spread of antibiotic resistance [61]. It should not, however, be used as a political tool.

\section{Humanitarian response}

Non-governmental partners such as MSF or the International Red Cross and Red Crescent Movement, as well as $\mathrm{UN}$ agencies such as UNHCR and IOM, are at the forefront of attempts to manage acute and lasting migratory flows, and are confronted with a considerable diversity of profiles and needs [89]. All too often, the humanitarian response is under such financial and time constraints that its only realistic objective is to help individuals and families survive the current trip and arrive at their next destination without an increase in their medical and psychosocial problems. A recurrent concern is that the international media only focus on migrants when they reach via dramatic journey a high-profile, and often high-income country. Obstacles to integration for regularly residing migrants need to be addressed as well, in the interest of public health and social cohesion. Furthermore, the vast majority of migrants are IDPs in Asia or Africa, where resources for vital interventions are often lacking. Proportionately, IDPs pay the highest burden for mortality, morbidity and malnutrition. Along the migratory pathways, there is a need to standardise diagnostic and treatment protocols, particularly because of chronic diseases requiring continuity of care. This has recently been a problem in many settings, from Lebanon to Ukraine.

The humanitarian response has had to handle many challenges that are either invisible or constantly overlooked, such as interpersonal violence or mental and sexual health. Other challenges include the safety of humanitarian and healthcare personnel [90]. If a hospital is attacked, beyond immediate victims, people will stop going there, which will engender more victims $[90,91]$. The Health Care in Danger Project (part of the International Red Cross and Red Crescent Movement) has documented 1809 attacks against healthcare providers worldwide in 2012-2013, 40\% of which were directed against healthcare facilities [92]. In the report, it was found that State armed and security forces (military and police) and armed non-State actors are equally involved in these attacks. Use of access to healthcare as a military strategy, known as the weaponisation of healthcare, as for example in Syria, is unacceptable [91]. Unfortunately, evidence suggests that these attacks may be increasing with time [90]. Warring parties and governments need to understand, respect and provide the basic provision of sanitation and health. Also, some migrants are not able or willing to wait for help to arrive: when a team comes to examine a group, it may have moved on, as was experienced by MSF in the Balkans in 2015-2016.

\section{Focus on policy}

The health strand of the Migration Integration Policy Index (MIPEX), collaboratively developed by IOM, has 38 indicators for health policy that can be measured and be addressed towards achieving health equity (health being one of eight sectors covered by MIPEX). Health indicators fall into four dimensions: entitlement to health services, policies to facilitate access, responsive health services and measures to achieve change. According to MIPEX, even well-performing host countries such as Germany or Sweden only achieve around 70\% health equity [93].

Policies towards migrants in Europe and the United States tend to be volatile and election-dependent. They are also poorly coordinated with each other. A case in point is the so-called "Dublin Treaty" (the Dublin III Regulation Number 604/2013 came into force on 19 July 2013) which makes the first EU Member State where fingerprints are stored or an asylum claim is lodged, responsible for a person's asylum claim. This is one of the reasons why Italy and Greece have had to deal with so many migrants and have consistently felt let down by the international community. This policy, as well as its underlying assumptions, has been criticised in the past by UNHCR, and the Parliamentary Assembly of the Council of Europe [94-97].

Because of the Dublin Treaty, many migrants are sent back to the first European country where they were 
registered, which is often Italy or Greece. These countries have limited perspectives for the realisation of their dreams of economic opportunity. Deportation to the first "Dublin" country often leads to depression, suicidal thoughts or risky behaviour such as unprotected sex or substance abuse.

At the UN General Assembly in September 2016, Member States issued the New York Declaration for Refugees and Migrants, which is a set of commitments as well as an action plan to implement these commitments [98]. This has resulted not only in the Comprehensive Refugee Response Framework, the core elements of which have been agreed on, and which contains four key elements (easing pressure on host countries, enhancing refugee self-reliance, expanding third-country solutions, and supporting conditions in countries of origin for return in safety and dignity), but also the Global Compact on Refugees which will be presented by the High Commissioner for Refugees at the General Assembly in September 2018 [99].

\section{Conclusion and way forward}

Humanitarian problems require political solutions, therefore political commitment is sorely needed to try to reduce the number of uprooted people, and improve their conditions when they are on the move. There is a need to work in a concerted manner on points of origin, points of transit and final points of destination.

The improvement of health of populations, as set out in the UN Sustainable Development Goals, which includes for the first time a migration target (Goal 10), requires the medical and scientific community to understand the complex dynamics of migration. A better grasp of the forces involved is necessary, using a trans-disciplinary approach combining humanitarian, economic, sociological and public health approaches. Accessing and improving basic rights including healthcare along transit routes is a definite priority.

Academics also have a responsibility in lending their voice to the cause of bettering the condition of migrants, and indeed many have taken or called for action [100, 101]. Conducting research that sheds light on the plight of migrants, or on how policy can negatively affect their existence is valuable. Improving awareness of primary-care teams to specific migrant health issues as well as transcultural dimensions by training is another such example [102]. One of the aims of the UCL-Lancet Commission on Migration and Health, a multidisciplinary group of academics, policymakers, and health system experts, is to "articulate evidence-base approaches to inform public discourse and policy"and will produce a report set to coincide with the UN General Assembly in September 2018 [103].

This article lends support to recent calls for improved governance mechanisms to ensure the integration of migration within health systems, currently designed for resident populations [104]. Whereas there always seem to be sufficient funds for walls, borders or barriers to the movement of people, more investment is necessary to achieve universal health coverage. Research within Germany has shown that regions that invested less in healthcare for migrants have ended up spending more in the long run [105]. Likewise, a review of the resources invested by the UNHCR in 70 sites in 17 countries shows that increased spending on refugee populations is correlated with lower mortality, reflecting not only efficacy on the part of humanitarian action but also the considerable vulnerability and dependence of migrant populations on international aid [106].

Health equity and early access to healthcare appear as critical responses to the migratory crisis. The principles of public health equity mean that medicine must be used to assist human populations in distress. This commitment at a global level must be followed by concerted actions in the field, where migrants need assistance and protection. Too often, they are denied healthcare or health insurance. If universal health coverage is to be achieved, it cannot be conditioned upon the status of any person [107].

Another point is the opportunity to look at the positive aspects of migration. Global remittances from migrants to their countries of origin have been estimated by the World Bank to be $\$ 429$ billion [108], which is higher than the "net official development assistance (ODA) flows from member countries of the Development Assistance Committee (DAC) of the OECD" of \$135.2 billion in 2014 [109]. Also, a majority of adult migrants have skills that could be put to good use [110-112]. Among migrants and refugees are engineers and healthcare professionals who are able and willing to help, but often cannot do this due to administrative hurdles. It makes sense to find ways of employing these professionals, thus breaking their economic dependence, whilst giving them recognition, and increasing cost-efficiency and the overall well-being of both migrant and host populations, not to mention stopping the drain of human resources affecting low-to middle income countries. This was recognized by the EU when it launched the "science4refugees" initiative [113]. Finally, much of the healthcare provided to migrants during the 2015-2017 crisis was by volunteers. These dedicated people need to be supported by sufficiently strong healthcare, administrative and financial systems [114].

In the words of the UN High Commissioner for Refugees, Filippo Grandi, we must "ask ourselves what each of us can do to overcome indifference or fear and to embrace the idea of inclusion, to welcome refugees to our own communities, and counter narratives that would seek to exclude and marginalise refugees and other uprooted people" [115].

Availability of data and materials

Data sharing not applicable to this article as no datasets were generated or analysed during the current study. 


\section{Authors' contributions}

$M A$ and DP were responsible for the organisation of the workshop, and were significantly assisted by SH. TA, JB, MC, SDP, LG, AJ, YJ, KK, DK, EM, MM, RPB and ST were participants in the workshop and the round-table and either gave presentations, moderated the workshop. DC and MS wrote the first draft of the manuscript, which was significantly edited by MA. All authors read and approved the final manuscript.

\section{Ethics approval and consent to participate}

Not applicable.

\section{Consent for publication}

The persons who have been photographed have provided consent that the photographs taken of them will may be published, and may be freely available on the internet and may be seen by the general public. Oral consent was provided to the photographer, and a form was not signed. It was not possible to contact the photographed persons for the purposes of signing a consent form.

\section{Competing interests}

The authors declare that they have no competing interests.

\section{Publisher's Note}

Springer Nature remains neutral with regard to jurisdictional claims in published maps and institutional affiliations.

\section{Author details}

${ }^{1}$ Infection Control Programme and WHO Collaborating Centre on Patient Safety, Faculty of Medicine, University of Geneva Hospitals, Geneva, Switzerland. ${ }^{2}$ Médecins sans Frontières, Geneva, Switzerland. ${ }^{3}$ CAPPI Servette, Department of Mental Health and Psychiatry, Geneva University Hospitals, Genève, Switzerland. ${ }^{4}$ International Centre for Migration, Health and Development, Geneva, Switzerland. ${ }^{5}$ Programme Santé Migrants, Department of Community Medicine, Primary Care and Emergency Medicine, Geneva University Hospitals, Geneva, Switzerland. ${ }^{6}$ Geneva, Switzerland. ${ }^{7}$ Department of Clinical Immunology and Rheumatology, Hannover Medical School, Hannover, Germany. ${ }^{8}$ German Center for Infection Research (DZIF), PARTNER Site Hannover-Braunschweig, Hannover, Germany. ${ }^{9}$ Division of Primary Care Medicine, Geneva University Hospitals, Geneva, Switzerland. ${ }^{10}$ Institute of Global Health, Geneva University, Geneva, Switzerland. ${ }^{11}$ Department of Service Delivery \& Safety, World Health Organization, Geneva, Switzerland. ${ }^{12}$ Division of Communicable Diseases, Federal Office of Public Health, Bern, Switzerland. ${ }^{13}$ Health Unit, International Committee of the Red Cross (ICRC), Geneva, Switzerland. ${ }^{14}$ Division of Infectious Diseases \& HIV Medicine, Department of Medicine, Groote Schuur Hospital, University of Cape Town, Cape Town, South Africa. ${ }^{15}$ International Organization for Migration (IOM), Migration Health Division (MHD), Regional office (RO), Brussels, Belgium. ${ }^{16} 4$ th Department of Medicine, Medical School, National and Kapodistrian University of Athens, Athens, Greece. ${ }^{17}$ Hellenic Centre for Disease Control \& Prevention, Athens, Greece. ${ }^{18}$ Division of environmental health, Institute of Global Health, Faculty of Medicine, University of Geneva, Geneva, Switzerland. ${ }^{19}$ Communication in Science, Geneva, Switzerland. ${ }^{20}$ Section of Infectious Diseases and Immunity, Department of Medicine, Imperial College London, Hammersmith Hospital, London W12 OHS, UK. ${ }^{21}$ The Institute for Infection and Immunity, St George's, University of London, London WC1E 7HU, UK.

Received: 25 April 2018 Accepted: 7 September 2018 Published online: 20 September 2018

\section{References}

1. International Organization for Migration. Missing Migrants Project. https://missingmigrants.iom.int/. Accessed 8 Sept 2017. 2017.

2. Dijstelbloem H. Migration tracking is a mess. Nature. 2017;543(7643):31-3.

3. International Organization for Migration. Who is a migrant? https://www. iom.int/who-is-a-migrant (accessed 01.03.2018)

4. Guterres A. World Refugee Day 2017 - Secretary-General Video Message. 20. 06.2017 2017. https://www.un.org/sg/en/content/sg/statement/2017-06-20/ secretary-generals-message-world-refugee-day (accessed 01.10.2017).

5. Nougayrède N. Refugees aren't the problem. Europe's identity crisis is. The Guardian. 2016;31:10. https://www.theguardian.com/commentisfree/2016/ oct/31/refugees-problem-europe-identity-crisis-migration. Accessed 1 June 2017.

6. Betts A. Survival Migration. Failed Governance and the Crisis of Displacement. Ithaca: Cornell University Press. 2013. http://www.jstor.org/ stable/10.7591/j.ctt32b5cd.

7. Burkle FM. The politics of global public health in fragile states and ungoverned territories. PLoS Currents 2017; 9: ecurrents.dis. ba3beede71ca0746a972aa3837ed618.

8. Hayes S, Lundy BD, Hallward MC. Conflict-induced migration and the refugee crisis: global and local perspectives from Peacebuilding and development. Journal of Peacebuilding \& Development. 2016;11(3):1-7.

9. OECD (2016), States of Fragility 2016: Understanding Violence, OECD Publishing, Paris. https://doi.org/10.1787/9789264267213-en.

10. World Health Organization. Office of the High Commissioner for human rights, International Organization for Migration. International migration, health and human rights. Geneva: International Organization for Migration; 2013.

11. da Costa R. Rights of refugees in the context of integration: legal standards and recommendations. Legal and protection policy research series. In: UNHCR; 2006.

12. Vernon A, Deriche K, Eisenhauer S. Connecting refugees. How Internet and Mobile Connectivity can Improve Refugee Well-Being and Transform Humanitarian Action. Geneva: UNHCR; 2016.

13. Gorst-Unsworth C, Goldenberg E. Psychological sequelae of torture and organised violence suffered by refugees from Iraq. Trauma-related factors compared with social factors in exile. Br J Psychiatry. 1998;172:90-4.

14. McColl H, Johnson S. Characteristics and needs of asylum seekers and refugees in contact with London community mental health teams - a descriptive investigation. Soc Psychiatry Psychiatr Epidemiol. 2006;41(10):789-95.

15. Kutzin J. Anything goes on the path to universal health coverage? No. Bull World Health Organ. 2012;90(11):867-8.

16. Ghebreyesus TA. All roads lead to universal health coverage. Lancet Glob Health. 2017:5(9):e839-e40.

17. Abiiro GA, De Allegri M. Universal health coverage from multiple perspectives: a synthesis of conceptual literature and global debates. BMC Int Health Hum Rights. 2015;15:17.

18. Fajardo-Dolci G, Gutierrez JP, Garcia-Saiso S. Effective access to health services: operationalizing universal health coverage. Salud publica de Mexico. 2015;57(2):180-6.

19. Chapman AR. Assessing the universal health coverage target in the sustainable development goals from a human rights perspective. BMC Int Health Hum Rights. 2016;16(1):33.

20. World Health Organization. Questions and answers on universal health coverage. http://www.who.int/healthsystems/topics/financing/uhc_qa. Accessed 8 Sept 2017.

21. UNICEF. A child is a child: protecting children on the move from violence. In: Abuse and exploitation; 2017.

22. International Organization for Migration. The push and pull factors of asylum-related migration: a literature review. 2016.

23. Newbold B, McKeary M. Investigating the diversity of Canada's refugee population and its health implications: does one size fit all? Int J Migr Health Soc Care. 2017:13(2):145-56

24. Kristiansen M, Razum O, Tezcan-Guntekin H, Krasnik A. Aging and health among migrants in a European perspective. Public Health Rev. 2016:37:14

25. Cheung SY, Phillimore J. Gender and refugee integration: a quantitative analysis of integration and social policy outcomes. J Soc Policy. 2017:46(2):211-30.

26. Shawyer F, Enticott JC, Block AA, Cheng IH, Meadows GN. The mental health status of refugees and asylum seekers attending a refugee health clinic including comparisons with a matched sample of Australian-born residents. Bmc Psychiatry. 2017;17:76

27. Fennelly K. The "healthy migrant" effect. Minn Med. 2007;90(3):51-3.

28. Norredam M, Agyemang C, Hansen $\mathrm{OKH}$, et al. Duration of residence and disease occurrence among refugees and family reunited immigrants: test of the 'healthy migrant effect' hypothesis. Tropical Med Int Health. 2014;19(8):958-67.

29. Hamilton TG. The healthy immigrant (migrant) effect: in search of a better native-born comparison group. Soc Sci Res. 2015;54:353-65.

30. Rubalcava LN, Teruel GM, Thomas D, Goldman N. The healthy migrant effect: new findings from the Mexican family life survey. Am J Public Health. 2008;98(1):78-84.

31. Arsenijevic J, Schillberg E, Ponthieu A, et al. A crisis of protection and safe passage: violence experienced by migrants/refugees travelling along the Western Balkan corridor to northern Europe. Confl Heal. 2017:11. 
32. Crepet A, Rita F, Reid A, et al. Mental health and trauma in asylum seekers landing in Sicily in 2015: a descriptive study of neglected invisible wounds. Confl Heal. 2017:11.

33. Keygnaert I, Dialmy A, Manco A, et al. Sexual violence and sub-Saharan migrants in Morocco: a community-based participatory assessment using respondent driven sampling. Glob Health. 2014:10.

34. Esposito F, Ornelas J, Arcidiacono C. Migration-related detention centers: the challenges of an ecological perspective with a focus on justice. BMC Int Health Hum Rights. 2015;15.

35. United Nations. Standard Minimum Rules for the Treatment of Prisoners. 30 August 1995. http://www.refworld.org/docid/3ae6b36e8.html (accessed 7 Nov 2017).

36. Institute for Criminal Policy Research. World Prison Brief. http://www. prisonstudies.org/highest-to-lowest/foreign-prisoners?field_region_ taxonomy_tid=14 (accessed 23.10.2017).

37. Aebi MF, Tiago MM, Burkhardt C. SPACE I - Council of Europe Annual Penal Statistics: prison populations. Survey 2015. Strasbourg: Council of Europe; 2016

38. Kazi AM, Shah SA, Jenkins CA, Shepherd BE, Vermund SH. Risk factors and prevalence of tuberculosis, human immunodeficiency virus, syphilis, hepatitis B virus, and hepatitis C virus among prisoners in Pakistan. Int J Infect Dis. 2010;14:E60-E6.

39. Kamarulzaman A, Reid SE, Schwitters A, et al. Prevention of transmission of HIV, hepatitis B virus, hepatitis C virus, and tuberculosis in prisoners. Lancet. 2016;388(10049):1115-26

40. International Organization for Migration. Summary report on the MIPEX health Strand and country reports. Geneva: International Organization for Migration; 2016.

41. Singer M, Bulled N, Ostrach B, Mendenhall E. Syndemics and the biosocial conception of health. Lancet. 2017;389(10072):941-50.

42. Rechel B, Mladovsky P, Devillé W, Rijks B, Petrova-Benedict R, McKee M. Migration and health in European Union. Maidenhead: McGraw Hill/Open University Press; 2011.

43. Bogic M, Ajdukovic D, Bremner S, et al. Factors associated with mental disorders in long-settled war refugees: refugees from the former Yugoslavia in Germany, Italy and the UK. Br J Psychiatry. 2012;200(3):216-23.

44. Gerritsen AAM, Bramsen I, Deville W, van Willigen LHM, Hovens JE, van der Ploeg HM. Physical and mental health of afghan, Iranian and Somali asylum seekers and refugees living in the Netherlands. Soc Psychiatry Psychiatr Epidemiol. 2006;41(1):18-26.

45. Fazel M, Wheeler J, Danesh J. Prevalence of serious mental disorder in 7000 refugees resettled in western countries: a systematic review. Lancet. 2005;365(9467):1309-14.

46. Coughlin SS. Anxiety and Depression: Linkages with Viral Diseases. Public Health Rev. 2012;34(2):92.

47. Doocy S, Lyles E, Roberton T, Akhu-Zaheya L, Oweis A, Burnham G. Prevalence and care-seeking for chronic diseases among Syrian refugees in Jordan. BMC Public Health. 2015;15.

48. Chauvin P, Parizot I, Simmonot N. L'accès aux soins de personnes sans autorisation de séjour dans 11 pays d'Europe. Paris: Observatoire Européen de l'accès aux soins de Médecins du Monde; 2009

49. Turktan $\mathrm{M}, \mathrm{Ak} \mathrm{O}$, Erdem $\mathrm{H}$, et al. Community acquired infections among refugees leading to intensive care unit admissions in Turkey. Int J Infect Dis. 2017;58:111-4.

50. Jackson Y, Paignon A, Wolff H, Delicado N. Health of undocumented migrants in primary care in Switzerland. PLoS One. 2018;13(7):e0201313.

51. Monge-Maillo B, Lopez-Velez R, Norman FF, Ferrere-Gonzalez F, MartinezPerez A, Perez-Molina JA. Screening of imported infectious diseases among asymptomatic sub-Saharan African and Latin American immigrants: a public health challenge. Am J Trop Med Hyg. 2015;92(4):848-56.

52. Errecaborde KM, Stauffer W, Cetron M. Neglected Tropical Disease Control and Elimination: Is Human Displacement an Achilles Heel. PLoS Negl Trop Dis. 2015;9(3):e0003535.

53. Mbabazi PS, Andan O, Fitzgerald DW, Chitsulo L, Engels D, Downs J. Examining the relationship between urogenital schistosomiasis and HIV infection. Tropical Med Int Health. 2013;18:55-6.

54. Kamal SM, Turner B, He Q, et al. Progression of fibrosis in hepatitis $C$ with and without schistosomiasis: correlation with serum markers of fibrosis. Hepatology. 2006;43(4):771-9.

55. Siegel MO, Simon GL. Is Human Immunodeficiency Virus Infection a Risk Factor for Strongyloides stercoralis Hyperinfection and Dissemination. Plos Negl Trop Dis. 2012;6(7):e1581.
56. Sartori AMC, Ibrahim KY, Westphalen EVN, et al. Manifestations of Chagas disease (American trypanosomiasis) in patients with HIVAIDS. Ann Trop Med Parasitol. 2007;101(1):31-50.

57. Tornesello ML, Giorgi Rossi P, Buonaguro L, Buonaguro FM. Group HPVPIW. Human Papillomavirus Infection and Cervical Neoplasia among Migrant Women Living in Italy. Frontiers in oncology. 2014;4:31.

58. Carballo M, Maclean E, Gudumac I. Van Damme P. Hepatitis C and Migration: A Public Health Challenge. J Fam Med. 2016;3(4):1065.

59. Ackermann N, Marosevic D, Hormansdorfer $S$, et al. Screening for infectious diseases among newly arrived asylum seekers, Bavaria, Germany, 2015. Euro Surveill. 2018;23(10):17-00176.

60. Bil JP, Schrooders PA, Prins M, et al. Integrating hepatitis B, hepatitis $C$ and HIV screening into tuberculosis entry screening for migrants in the Netherlands, 2013 to 2015. Eurosurveillance. 2018;23(11):17-00491.

61. Ravensbergen SJ, Berends M, Stienstra Y, Ott A. High prevalence of MRSA and ESBL among asylum seekers in the Netherlands. PLoS One 2017; 12(4):e0176481.

62. Seedat F, Hargreaves S, Nellums LB, Ouyang J, Brown M, Friedland JS. How effective are approaches to migrant screening for infectious diseases in Europe? A systematic review. Lancet Infect Dis. 2018;18(9):e259-e71.

63. Murcia L, Simon M, Carrilero B, Roig M, Segovia M. Treatment of infected women of childbearing age prevents congenital Trypanosoma cruzi infection by eliminating the Parasitemia detected by PCR. J Infect Dis. 2017:215(9):1452-8.

64. Sicuri E, Munoz J, Pinazo MJ, et al. Economic evaluation of Chagas disease screening of pregnant Latin American women and of their infants in a non endemic area. Acta Trop. 2011;118(2):110-7.

65. Nakken CS, Skovdal M, Nellums LB, Friedland JS, Hargreaves S, Norredam M. Vaccination status and needs of asylum-seeking children in Denmark: a retrospective data analysis. Public Health. 2018;158:110-6.

66. Paxton GA, Rice J, Davie G, Carapetis JR, Skull SA. East African immigrant children in Australia have poor immunisation coverage. J Paediatr Child Health. 2011:47(12):888-92.

67. de Monleon JV, Regnier F, Ajana F, et al. catch-up vaccination of worldwide newcoming (adopted, refugee or migrant) children in France. Arch Pediatr. 2014;21(3):329-34

68. Jablonka A, Happle C, Wetzke M, et al. Measles, rubella and varicella lgG Seroprevalence in a large refugee cohort in Germany in 2015: a crosssectional study. Infect Dis Ther. 2017:6(4):487-96.

69. Mipatrini D, Stefanelli P, Severoni S, Rezza G. Vaccinations in migrants and refugees: a challenge for European health systems. A systematic review of current scientific evidence. Pathog Glob Health. 2017;111(2):59-68.

70. Jones $\mathrm{G}$, Haeghebaert S, Merlin B, et al. Measles outbreak in a refugee settlement in Calais, France: January to February 2016. Euro Surveill. 2016;21(11):30167.

71. Lesens O, Baud O, Henquell C, Lhermet Nurse A, Beytout J. Varicella outbreak in Sudanese refugees from Calais. J Travel Med. 2016;23(5):042.

72. Mellou K, Chrisostomou A, Sideroglou T, et al. Hepatitis a among refugees, asylum seekers and migrants living in hosting facilities, Greece, April to 2016. Euro Surveill. 2017:22(4):30448.

73. WHO Regional Office per Europe. WHO-UNHCR-UNICEF Joint Technical Guidance: General Principles of Vaccination of Refugees, Asylum-Seekers and Migrants in the WHO European Region. 3 November 2015. http://www.euro.who.int/en/health-topics/disease-prevention/ vaccines-and-immunization/news/news/2015/11/who,-unicef-andunhcr-call-for-equitable-access-to-vaccines-for-refugees-and-migrants/ who-unhcr-unicef-joint-technical-guidance-general-principles-ofvaccination-of-refugees,-asylum-seekers-and-migrants-in-the-whoeuropean-region]. Accessed 24 Aug 2018.

74. European Centre for Disease Prevention and Control. ECDC technical document: infectious diseases of specific relevance to newly-arrived migrants in the EU/EEA. Stockholm; 2015. https://ecdc.europa.eu/sites/ portal/files/media/en/publications/Publications/Infectious-diseases-ofspecific-relevance-to-newly-arrived-migrants-in-EU-EEA.pdf]. Accessed 24 Aug 2018.

75. Hargreaves $S$, Nellums LB, Ramsay M, et al. Who is responsible for the vaccination of migrants in Europe. Lancet. 2018;391(10132):1752-4.

76. Giambi C, Del Manso M, Dente MG, et al. Immunization Strategies Targeting Newly Arrived Migrants in Non-EU Countries of the Mediterranean Basin and Black Sea. Int J Environ Res Public Health. 2017;14(5):E459.

77. Ginsburg AS, Klugman KP. Vaccination to reduce antimicrobial resistance. Lancet Glob Health. 2017;5(12):e1176-e7. 
78. Kumar S. Reduction in antimicrobial resistance by the way of extensive vaccination. Hum Vaccin Immunother. 2018:1-2

79. Tagliabue A, Rappuoli R. Changing priorities in Vaccinology: antibiotic resistance moving to the top. Front Immunol. 2018;9:1068.

80. Jansen KU, Knirsch C, Anderson AS. The role of vaccines in preventing bacterial antimicrobial resistance. Nat Med. 2018;24(1):10-9.

81. Atkins KE, Lafferty El, Deeny SR, Davies NG, Robotham JV, Jit M. Use of mathematical modelling to assess the impact of vaccines on antibiotic resistance. Lancet Infect Dis. 2018;18(6):e204-e13.

82. Wilson ME. Travel and the emergence of infectious-diseases. Emerg Infect Dis. 1995;1(2):39-46.

83. European Centre for Disease Prevention and Control (ECDC). Infectious diseases of specific relevance to newly-arrived migrants in EU/EEA. Stockholm: ECDC; 2015.

84. Soto SM. Human migration and infectious diseases. Clin Microbiol Infect. 2009;15:26-8.

85. Nellums L, Hargreaves S, Thompson H, Friedland JS. Antimicrobial resistance in migrants to Europe. Vienna: European Congress of Clinical Microbiology and Infectious Diseases; 2017.

86. de Smalen AW, Ghorab H, Abd El Ghany M, Hill-Cawthorne GA. Refugees and antimicrobial resistance: a systematic review. Travel Med Infect Dis 2017; 15: 23-28

87. Nellums LB, Thompson $\mathrm{H}$, Holmes $\mathrm{A}$, et al. Antimicrobial resistance among migrants in Europe: a systematic review and meta-analysis. Lancet Infect Dis. 2018;18(7):796-811.

88. Hargreaves S, Lonnroth K, Nellums LB, et al. Multidrug-resistant tuberculosis and migration to Europe. Clin Microbiol Infect. 2017;23(3):141-6.

89. Trovato A, Reid A, Takarinda KC, et al. Dangerous crossing: demographic and clinical features of rescued sea migrants seen in 2014 at an outpatient clinic at Augusta Harbor, Italy. Confl Health. 2016;10:14.

90. Briody C, Rubenstein L, Roberts L, Penney E, Keenan W, Horbar J. Review of attacks on health care facilities in six conflicts of the past three decades. Confl Health. 2018;12:19.

91. Fouad FM, Sparrow A, Tarakji A, et al. Health workers and the weaponisation of health care in Syria: a preliminary inquiry for the lancet-American University of Beirut Commission on Syria. Lancet. 2017:390(10111):2516-26.

92. Health care in danger. Violent incidents affecting the delivery of health care. January 2012 to December 2013: International Committee of the Red Cross, 2014.

93. Huddleston T, Bilgili O, Joki A-L, Vankova Z. Migrant integration policy index 2015. 2015.

94. United Nations High Commissioner for Refugees (UNHCR). UNHCR Position on the Return of Asylum-Seekers to Greece Under the "Dublin Regulation". Geneva: UNHCR; 2008.

95. United Nations High Commissioner for Refugees (UNHCR). UNHCR Comments on The European Commission Proposal for a Recast Dublin Regulation. Geneva: UNHCR; 2016.

96. Parliamentary Assembly of the Council of Europe. Resolution 2072 (2015). Strasbourg: Council of Europe; 2015.

97. Parliamentary Assembly of the Council of Europe. Resolution 2000 (2014). Strasbourg: Council of Europe; 2014

98. New York Declaration for Refugees and Migrants. New York: United Nations, 2016.

99. United Nations High Commissioner for Refugees (UNHCR). New York Declaration for Refugees and Migrants. http://www.unhcr.org/new-yorkdeclaration-for-refugees-and-migrants.html. Accessed 13 Mar 2018.

100. Hargreaves S. Europe's migrants face unacceptable humanitarian situation. Lancet Infect Dis. 2016;16(1):27-8.

101. Carballo M, Hargreaves S, Gudumac I, Maclean EC. Evolving migrant crisis in Europe: implications for health systems. Lancet Glob Health. 2017;5(3):e252-e3.

102. Afkhami AA. Can academic medicine Lead the way in the refugee crisis? Acad Med. 2016:91(12):1595-7.

103. UCL-Lancet Commission on Migration and Health. About the Commission. https://www.migrationandhealth.org/about (accessed 12.03.2018).

104. Hanefeld J, Vearey J, Lunt N. Researchers migration M. a global research agenda on migration, mobility, and health. Lancet. 2017;389(10087):2358-9.

105. Bozorgmehr K, Razum O. Effect of restricting access to health care on health expenditures among asylum-seekers and refugees: a quasi-experimental study in Germany, 1994-2013. PLoS One. 2015;10(7):e0131483.

106. Tan TM, Spiegel P, Haskew C, Greenough PG. Does spending on refugees make a difference? A cross-sectional study of the association between refugee program spending and health outcomes in 70 sites in 17 countries. Confl Health. 2016:10:28.

107. Ingleby D, Petrova-Benedict R. Recommendations on access to health services for migrants in an irregular situation: an expert consensus. Brussels: International Organization for Migration (IOM) Regional Office Brussels, Migration Health Division; 2016.

108. World Bank. Migration and development brief, 27 April 2017. 2017.

109. Fromentin $\mathrm{V}$. The long-run and short-run impacts of remittances on financial development in developing countries. 2017.

110. Organisation for Economic Co-operation and Development (OECD). Labour market integration of immigrants and their children: developing, activating and using skills. In: International migration outlook, vol. 2014. Paris: OECD Publishing; 2014.

111. Organisation for Economic Co-operation and Development (OECD). How can migrants' skills be put to use? Migration Policy Debates, 2014. Access 01.10.2017).

112. Macchiavello M. Forced migrants as an under-utilized asset: refugee skills, livelihoods, and achievements in Kampala, Uganda. Working paper no. 95 Geneva: UNHCR; 2003

113. Commission launches initiative to help refugee scientists and researchers. 2015. http://ec.europa.eu/research/index.cfm?pg=newsalert\&year=2015\&na= na-051015 (accessed 23.10.2017)

114. Kitching GT, J. Haavik H, Tandstad BJ, Zaman M, Darj E. Exploring the role of ad hoc grassroots organizations providing humanitarian aid on Lesvos. Greece PLOS Currents. 2016;8 ecurrents.dis. bd282cd90ade7d4eb63b6bbdb1904d10.

115. Grandi F. World Refugee Day Statement By Filippo Grandi, United Nations High Commissioner for Refugees. 20.06.2017. http://www.unhcr.org/admin/ hcspeeches/5948d38e7/world-refugee-day-statement.html (accessed 01.10.2017).

\section{Ready to submit your research? Choose BMC and benefit from:}

- fast, convenient online submission

- thorough peer review by experienced researchers in your field

- rapid publication on acceptance

- support for research data, including large and complex data types

- gold Open Access which fosters wider collaboration and increased citations

- maximum visibility for your research: over $100 \mathrm{M}$ website views per year

At $\mathrm{BMC}$, research is always in progress.

Learn more biomedcentral.com/submissions 